\title{
The role of meteorological variables of blossoming and ripening within the tendency of qualitative indexes of sour cherry
}

\author{
Lakatos, L. ${ }^{1}$, Szabó, T. ${ }^{2}$, Sun, $Z^{4}$, Soltész, M. $^{3}$, Szabó, Z. ${ }^{3}$, Dussi, M.C. ${ }^{5} \&$ Nyéki, J. ${ }^{3}$ \\ ${ }^{1}$ University of Debrecen, Centre for Agricultural Sciences and Engenering, Hungary \\ ${ }^{2}$ Fruit Research and Extension Institute of Ujfehértó, Hungary \\ ${ }^{3}$ University of Debrecen, Institute for Research and Development, Hungary \\ ${ }^{4}$ CAAS, Beijing, Institute of Vegetable and Flower Science \\ ${ }^{5}$ Fucultad de Ciencias Agrarias, Universidad Nacional del Comahue
}

\begin{abstract}
Summary: We analyzed the relationship to sour cherry quality parameters of average temperature, maximum temperature, minimum temperature, night and day-time temperature, precipitation and climatic water balance variables. Three cultivars of sour cherry were included in the selection: "Debreceni bőtermő", "Kántorjánosi", and "Újfehértói fürtös". We conducted regression analyzes on the three varieties, but present only those that proved to be the best fit. We couldn't find any significant differences in the weather tolerance of the varieties. The data base of sour cherry quality parameters covers the 1998 to 2008 intervals. The researched parameters were the following: dry matter content $(\%)$, sugar content $(\%), \mathrm{C}$-vitamin $(\mathrm{mg})$, total acid content $(\%)$. Maximum temperature, the difference of night and day-time temperature and minimum temperature all have a significant correlation with the investigated quality parameters of sour cherry. Minimum temperature shows a quadratic relationship with sugar content, while night and day-time temperature differences show the same with dry matter content. The other weather parameters had a linear correlation with the quality parameters of sour cherry. The research results show that an increasing amount of precipitation causes decreasing tendency in total acid content of sour cherry, so that increasing temperature has a positive influence on total acid content. Big differences in night and day-time temperature also has positive effects on the dry matter and sugar content of sour cherry while the amount of precipitation has a negative effect. High minimum temperatures cause decreasing sugar content respiratory energy losses are significant if dawn temperatures do not drop considerably. A more favourable climatic water balance has a positive effect on vitamin $\mathrm{C}$ content in cases of a large negative water balance, vitamin $\mathrm{C}$ content is generally low.
\end{abstract}

Key words: maximum-minimum temperature, climatic water balance, night and day temperature quality parameters, sugar content, $\mathrm{C}$ vitamin content, total acid content

\section{Introduction}

Sour cherry is one of our most important fruits. Its origins go back far, Hungarians have already known it in the ancient land of origin (Soltész et al.,1997). Although it is 4th-5th among our fruits, in view of commercial fruits it is the next after apple (Apostol, 1990). Trade of the current amount is already problematic; therefore further increase of quantity is not an objective. However, by means of quality improvement we may keep and strengthen our market positions (Kállayné, 1996). Environmental conditions for good quality sour cherry production are convenient in Hungary (Pór, 1982). Sour cherry adapts well to our climatic conditions. It tolerates low winter temperatures. By the time of blossoming it even tolerates minus $2{ }^{\circ} \mathrm{C}$ degrees as well. We involved 3 highly productive varieties, which are good substitutes for 'Pándy' sour cherry (Petö, 1978; Szabó, 1995).

Analysis of the qualitative parameters of sour cherry was aimed at its anthocyanin content so far (Blando et al., 2005). A very small number of publications have been published about the connection of sour cherry growth and weather
(Heide, 2007). These works focused mainly on the effect of daytime and night temperatures (Downs and Borthwick, 1956). Numerous analyses were aimed at the determination of the stone/flesh ratio (Faluba, 1982; Szabó, 1995). These results have mainly been used for the ranking of varieties. No close connection has been found between the size of the fruit and the stone. Fruit and stone size and stone/flesh ratio are not influenced by the maturing time of a variety either (Cociu, 1981b). Consumption value of freshly consumed fruits (Soltész et al., 1997) is determined by the following characteristics:

Primarily important: maturing time, fruit size, skin colour, taste, flavour, sugar and acid content, flesh integrity; (We analysed sugar and acid content among the mentioned parameters). Secondly important: stone size, vitamin, smell, flesh colour, presence of the stem (Only the analysis of vitamin content took place). In view of qualitative expectations, the most difficult is to meet the requirements of quick-freezing. Varieties with the following characteristics are suitable: at least medium large fruits, high anthocyanin content, and good colour, contentual values are favourable 
both freshly and after defrost. The following are considered to be very important parameters that determine fruit quality: size, shape, shape index, stem depth, stem length and thickness, stem separation from the fruit, wax surface, basic colour, inequality of colour and maturity, fruit crack (Nyéki et.al.,1997; Kerek et al.,1998; Soltész 1998a; Szabó, 1998; Szabó et al., 1998; Gonda et al., 2000).

\section{Material and method}

\section{Characteristics of the production area}

Újfehértó belongs to the physical geographic area of Nyírség, where the characteristic topographical and pedological conditions can be found. The main soil types within the area are humous sand, East European brown forest soils and meadow soils. The surface of the area of the Research Station is mildly wavy and cut up by macro- and micro depressions. The main soil type is non-carbonate, humous sand soil formed on muddy sand basis.

Based on a soil analysis carried out in the Pedological Laboratory of the Plant and Soil Conservation Service of Hajdú-Bihar County the main characteristics of a $60 \mathrm{~cm}$ layer of the soil profile are the following:

\begin{tabular}{|l|c|c|}
\hline Acidity & pHwet & 6,10 \\
\hline Lime content & $\%$ & $<0,1$ \\
\hline Water soluble salt & $\%$ & $<0,02$ \\
\hline Hydrolytic acidity & $\mathrm{y} 1$ & 7,2 \\
\hline Fixity & KA & 28 \\
\hline Humus content & $\%$ & 0,78 \\
\hline Thickness of the humous layer & $\mathrm{cm}$ & 60 \\
\hline
\end{tabular}

Acidity of the soil is mildly acidic, its organic matter content is medium within its category, and its physical sort is sand. The water level of the soil is below $250 \mathrm{~cm}$.

\section{Method}

The varieties analysed at the Research Station in Újfehértó are kept under completely identical production area and growth circumstances (growth area $/ 8 \times 5 \mathrm{~m} /$, crown shape /branch group/, phyto- and agro-technology, plant protection). The trees can be found on a mahaleb subject. The analytical samples have been collected from random block sample plots approved and registered by the National Institute for Agricultural Quality Control.

The fruit-product value (fruit size and weight, stone weight, stipule foliation) of the selected varieties have been carried out based on the methodological publication "Observation system of fruit trees within trials" published in 1976 by the National Institute for Agricultural Quality Control.

We analysed the main content characteristics of fruits (dry matter content, sugar content, acid content, vitamin $\mathrm{C}$ content) with the cooperation of the accredited laboratory of the Centre of Agricultural Sciences of the University of Debrecen, considering the relevant standards.

We evaluated the data by means of the traditional statistic methods described by Sváb and by means of Microsoft Excel and SPSS 12.0 for Windows software.

\section{Results}

\section{Total acid content}

Amount of precipitation has a significant role in the tendency of total acid content. Precipitation amount of the period between blossoming and maturity showed a significant connection (on $\mathrm{P}=1 \%$ level) with the total precipitation of the growing period only in the case of the 'Kántorjánosi' sour cherry variety (Figure 1). Based on the linear regression connection we can state that in case of higher precipitation amounts acid content of the fruit is lower, while in dry years with little precipitation sour cherry has higher acid content.

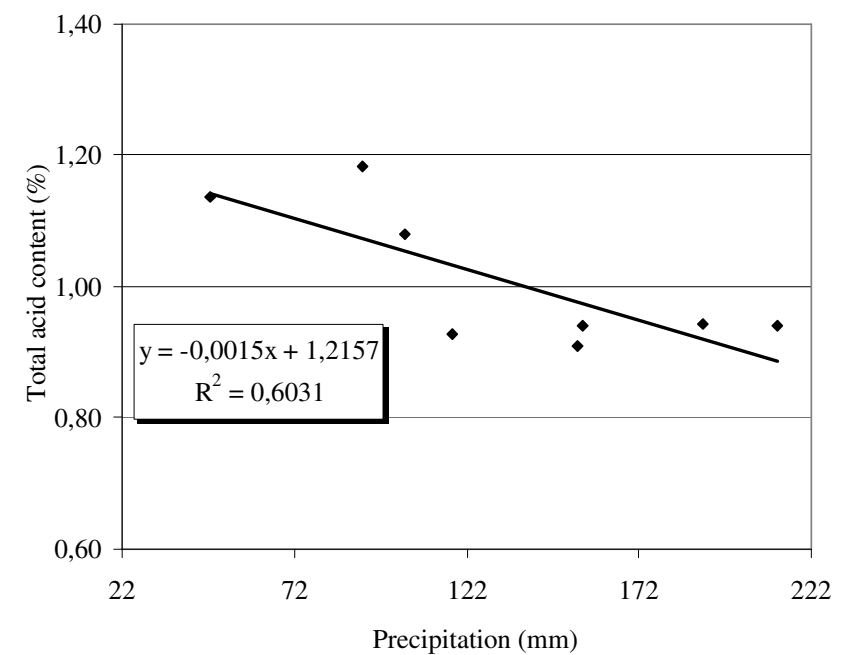

Figure 1: Relationship between the amount of precipitation of bloming to ripening period and total acid content of "Kántorjánosi" cultivar (Újfehértó, 1998-005)

Total acid content shows a close significant connection with maximum temperature as well (Figure 2). In years with higher temperature total acid content is higher than in chillier years.

\section{Dry matter content}

Precipitation of the period between blossoming and maturity has a significant role in the dry matter content tendency of sour cherry. We can state that in case of increasing precipitation amounts dry matter content at maturity decreases significantly (Figure 3). In years with abundant precipitation the analysed fruits had lower dry matter contents. 


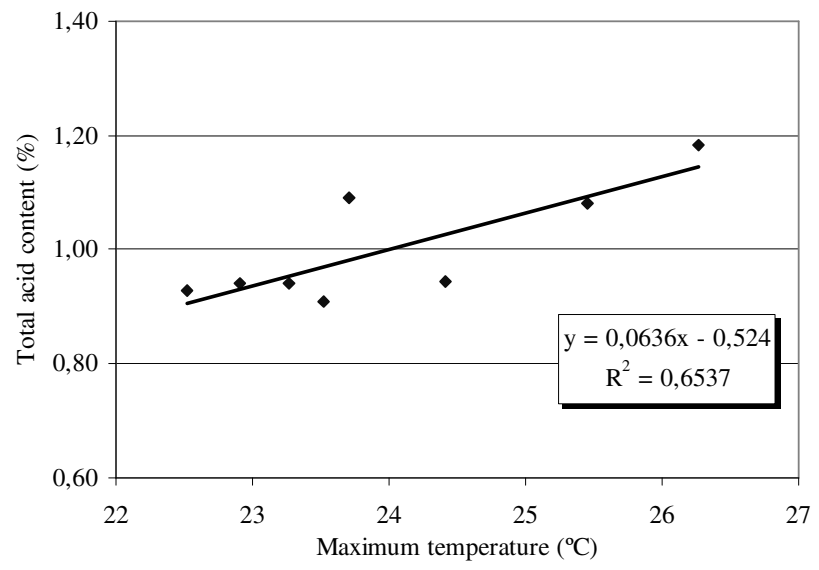

Figure 2: Relationship between the average maximum temperature and total acid content of "Kántorjánosi" cultivar from blooming to ripening (Újfehértó, 1998-2005)



Figure 3: Relationship between the amount of precipitation of blooming to ripening period and dry matter content of "Újfehértói fürtös" cultivar (Újfehértó, 1998-2005)

In addition, dry matter content also showed a significant connection with the difference of the average daytime and night temperatures. The regression connection is shown by Figure 4. The connection can be best characterized by second-degree polynomials. The connection informs us about the fact that in years when there is a significant difference between daytime and night temperatures dry matter content of sour cherry was higher than in years when this temperature difference reached only low values. The second-degree character indicates that in case of extraordinary temperature difference dry matter content does not follow linear increase anymore, but it decreases.

\section{Sugar content}

Similarly to dry matter content, tendency of sugar content is also influenced by the difference between daytime and night temperatures of the growing period. In the case of the 'Kántorjánosi' sour cherry variety (on $\mathrm{P}=1 \%$ level) we found a significant connection between the difference of the average daytime and night temperatures during the period between blossoming and maturity and the sugar content of sour cherry (Figure 5). The linear regression connection

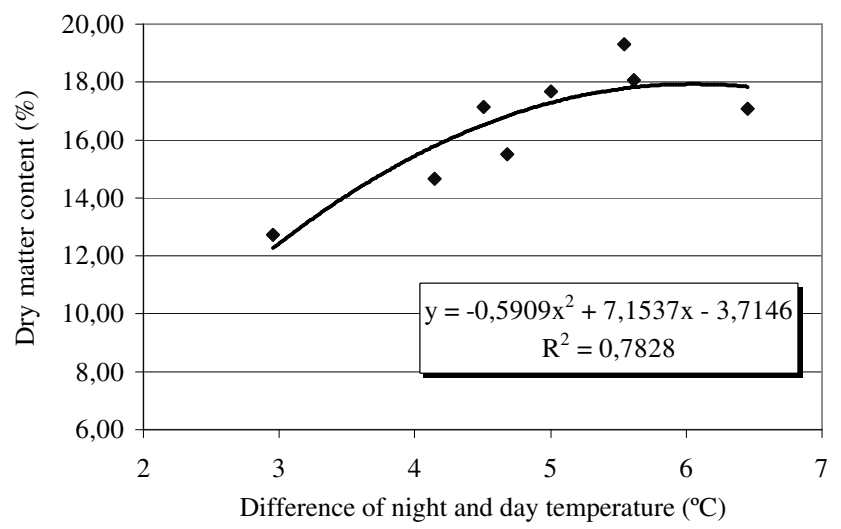

Figure 4: Relationship between average difference of night and day temperature and dry matter content of "Debreceni bőtermő" cultivar from blooming to ripening (Újfehértó, 1998-2005)

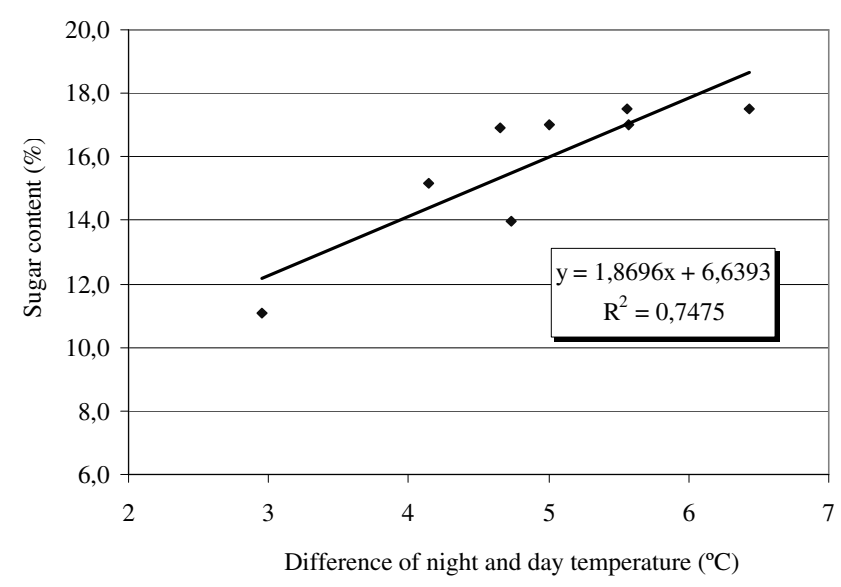

Figure 5: Relationship between the average value of the difference of night and day temperature and sugar content of "Kántorjánosi" cultivar from blooming to ripening (Újfehértó, 1998-2005)

indicates that the larger is the difference of daytime and night temperatures the higher sugar content we can expect in the case of sour cherry. Tendency of sugar content is also influenced by the changes of minimum temperature. In years when the average of minimum temperatures is high, fruits usually have lower sugar content. The connection between minimum temperature and sugar content in the case of the 'Újfehértói fürtös' variety is shown in Figure 6. The character of the connection is a second-grade polynomial, which means that the maximum values of sugar content occur at certain values of minimum temperature; in the case of very low or very high temperatures sour cherry has lower sugar content.

\section{Vitamin C}

Water availability conditions have a significant role in the tendency of vitamin C content. We can state that in years with sufficient water supply - when the climatic water balance has small negative values, or maybe it is zero or has a positive value - the analysed fruits have higher vitamin $\mathrm{C}$ content. The regression connection between climatic water balance during the growing period and vitamin $\mathrm{C}$ content is shown by 


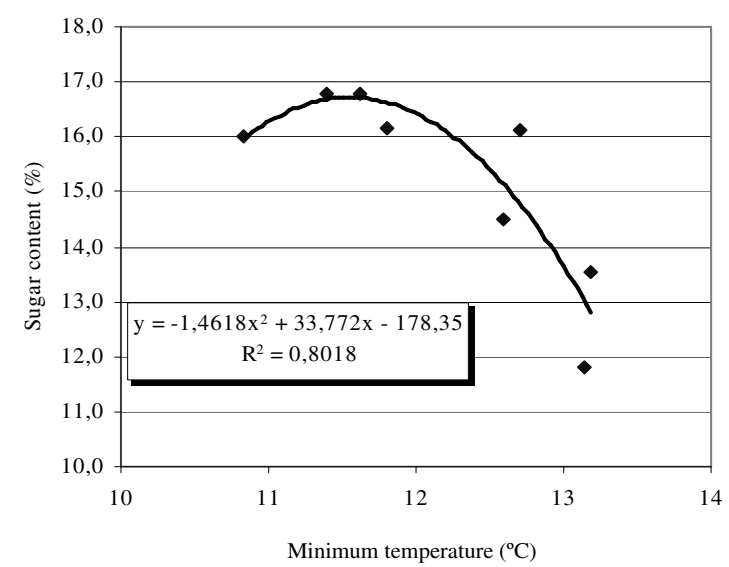

Figure 6: Relationship between average minimum temperature and sugar content of "Újfehértói fürtös" cultivar from blooming to ripening (Újfehértó, 1998-2005)

Figure 7. In the case of the 'Debreceni bötermö' sour cherry variety vitamin $\mathrm{C}$ content is lower in years with large water shortage, while in the case of a growing period with good water supply high vitamin $\mathrm{C}$ concentrations can be measured in the case of sour cherry.

\section{References}

Apostol, J. (1990): GyDKFV, ÁGOE Gyümölcstermesztési Szakbizottság és MAE Kertészeti Társaság közös rendezvényének előadásai, Budatétény, 1990. március 21.

Blando, F., Scardino, A. P., De Bellis, L., Nicoletti, I. \& Goivanazzo, G. (2005): Characterization of in vitro anthocyaninproducing sour cherry (Prunus cerasus L.) callus cultures Food Research International, 38: 937-942.

Cociu, V., Gozob, T., Rudi, E., Amzár, V. \& Micu, CH. (1981): Lucrarile Stiintifice, 9: 273-284

Downs \& Borthwick, R.J (1956): Effect of photoperiod on growth of trees, Bot. Gaz. 117: 310-326.

Faluba, Z. (1982): (In: Pór J. és Faluba Z. (szerk.), Cseresznye és meggy) Mezőgazdasági Kiadó, Budapest, 56-98.

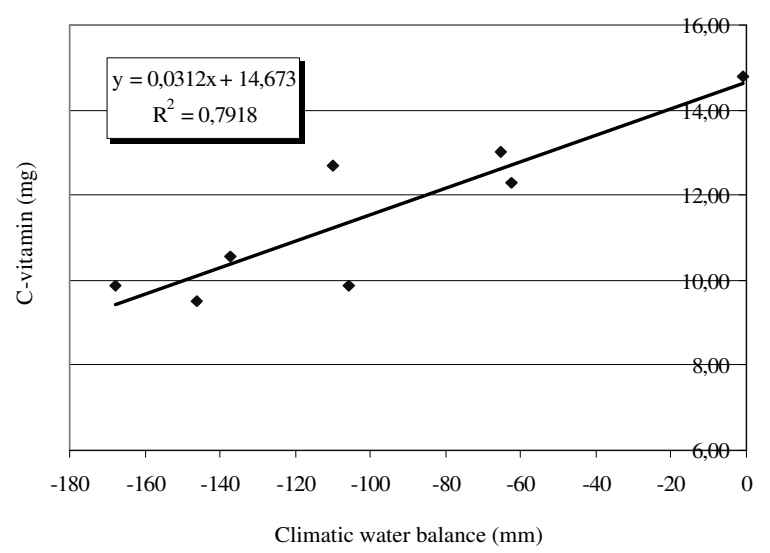

Figure 7: Relationship between the climatic water balance of blooming to ripenig period and C-vitamin content of "Debreceni bőtermő" cultivar (Újfehértó, 1998-2005)

Gonda, I., Holb, I. \& Bitskey, K. (2000): Rate of scab infection and quality parameters of apple fruit in organic and integrated production systems. Int. J. Hortic. Sci., 6 (4): 63-67.

Heide, O.M. (2007): Interaction of photoperiod and temperature in the control of growth and dormancy of Prunus species Scientia Horticulturae

Kállay, T.-né (1996): Új Kertgazdaság 2 (2): 65-69

Kerek, M. M., Nyujtó, F. \& Erdős, Z. (1998): A kajszibarack és a szilva minőségi követelményei

Pethö, F. (1978): Kertészet és Szőlészet 27 (1): 5.

Pór, J. (1982): (In: Pór J. és Faluba Z. (szerk.), Cseresznye és meggy) Mezőgazdasági Kiadó, Budapest. 108-116., 125-153., 188-221., 283-345. p.

Soltész, M. (szerk.) (1997): Integrált gyümölcstermesztés. Mezőgazda Kiadó, Budapest.

Soltész, M. (1998a): Gyümölcs fajtaismeret és -használat. Mezögazda Kiadó, Budapest, 513. p.

Szabó, T. (1995): Horticultural Science 27 (3-4): 29-33

Szabó, T. (1998): A cseresznye és a meggy gyümölcsminőségét kifejező mutatók és jellemzők. „AGRO 21” Füzetek 25: 79-86.

Szabó, Z., Nyéki, J. \& Soltész, M. (1998): Az őszibarack és a nektarin minőségét meghatározó tényezők. „AGRO 21” Füzetek 25: 54-65. 